Article

\title{
Environmental Conflicts Related to Urban Expansion Involving Agrarian Communities in Central Mexico
}

\author{
Victoria Ruiz Rincón * , Joan Martínez-Alier and Sara Mingorria \\ Institute of Environmental Science and Technology, Universitat Autònoma de Barcelona (ICTA-UAB), \\ Cerdanyola del Vallès, 08193 Barcelona, Spain; joanmartinezalier@gmail.com (J.M.-A.); \\ sara.mingorria@gmail.com (S.M.) \\ * Correspondence: victoria.ruizrincon@gmail.com
}

Received: 15 August 2019; Accepted: 8 November 2019; Published: 20 November 2019

check for updates

\begin{abstract}
Rural territories and cultures have been increasingly sacrificed through depopulation, invasion by infrastructure, and the presence of industries which are incompatible with agriculture. Meanwhile, the expansion of urban space through demographic agglomeration and the concentration of activities in cities is leading to a progressively urbanised world. This article sheds light on the particularities of the relationship between urban expansion and the assault on agrarian modes of existence that survive at the diffuse urban frontiers in Central Mexico. A multiple case study was carried out; nine social-environmental conflicts where an agrarian community resisted the installation of urban infrastructure or city enterprises were analysed through the perspective of Political Ecology and environmental justice. Peasant communities question the political, economic, environmental, and cultural factors of the hegemonic social configuration as urban megaprojects menace their territory. In their struggles, they highlight that urban development undermines the very conditions necessary for the existence of the city, as its social metabolism depends in part on the resources these rural communities are defending.
\end{abstract}

Keywords: urban sprawl; socio-environmental conflicts; urban infrastructure; social metabolism; depeasantisation

\section{Introduction}

One of the greatest social changes of the last century, the disappearance of the world's peasantry, was evidenced in 2007 when for the first time, most of the world's population lived in cities [1]. This phenomenon has profound environmental implications as it represents a planetary territorial transformation. The notion of "planetary urbanisation" [2,3] has been applied to this transformation, referring to spaces of resource extraction and waste disposal as structural expressions of what comprises cities. The study of urban social metabolism $[4,5]$ has also pointed to the unsustainability of cities and their dependence on the provision of external resources.

The way in which conditions of urban existence, namely the provision of resources, and waste disposal services are made socially "invisible" has given birth to the "urban fetish" [6]. The production of the city is blurred from people's awareness; therefore, the city has been the major representative of an ideology of progress. The growth of the city is seen as beneficial, and implausible "sustainable urbanisation" policies are embraced. Nevertheless, the city is put into question when social and environmental protests spring up due to the uneven distribution of social, environmental, cultural, and economic benefits and costs.

Political ecology has studied the many socio-environmental conflicts born from extractivism, and from this perspective, the systematic assault on agrarian modes of existence that megaprojects (mining, dams, roads, fossil fuel extraction) cause in the rural space through the dispossession and 
degradation of communities' livelihoods [7]. Research has also been conducted into the neoliberal type of urban planning that tends to be exclusive and privatising. Regarding urban expansion in Mexico, specifically, there have been many studies that focus on Mexico City's urban expansion since the 1950s. Azuela $[8,9]$ discusses agrarian opposition to urban expropriation dating back to the mid-20th century. Studies made by Cruz [10-13] analyse the interaction between urban and rural components and detail how much agrarian land has been urbanised during the last decades and argue that despite urban spaces reaching peasant communities at the frontiers, agricultural work has survived, and the rural identity has been reconstructed. Here, we analyse in detail the processes allowing the incorporation of agricultural land into urban use. Therefore, our objective is to analyse the way in which spatial expansion of the city or "urban sprawl" ("Urban sprawl" was first used in a short article published in Fortune magazine in January 1958 entitled simply "Urban Sprawl". The author William H. Whyte observed that "huge patches of once green countryside were turned into vast, smog-filled, deserts that were neither city, suburb, nor country. It was not merely that the countryside was ever-receding, but in the great expansion of the metropolitan areas, the subdivisions of one city were beginning to meet up with the subdivisions of another" [14]) contributes to the phenomenon of depeasantisation in Central Mexico. We emphasise the agrarian opposition to urbanisation beyond issues of compensation. We also emphasise the environmental arguments.

The Mexican context provides an interesting and holistic overview of the depeasantisation [15] and urbanisation phenomena. As a resource-rich territory, Mexico's economic growth has long been dependent on extractive industries, which in turn have triggered the accelerated growth of cities. Mexico City is the fifth-largest urban agglomeration in the world, and its expanding dynamics are far from static. Its influence can be observed throughout the whole central region of the country. Additionally, the historical political character of peasant communities in Mexico and the social movements they often promote to resist new enterprises or infrastructure facilitating capital accumulation in their land, represent dissident initiatives that challenge the global forces behind international and national development strategies such as the New Urban Agenda at Habitat III [16].

This paper analyses nine socio-environmental conflicts located in Central Mexico's megalopolis. It exposes the megaprojects (real estate developments of thousands of houses, airports, highways, and other transport infrastructure) with which the urban space pushes its limits. Backed by the state through promotion, facilitation, and corruption or repression practices, urbanisation projects respond to a neoliberal development agenda whose main objective is to push economic growth by prioritising the flow of capital and goods over environmental, social, and cultural values. Some peasant communities have resisted successfully to these enterprises while others are being dissociated of their means of production through land and other resources dispossession. In their struggles, they highlight that this type of development undermines the very conditions necessary for the existence of the city, as its social metabolism depends in part on the resources these rural communities are defending.

\section{Background}

\subsection{Global Depeasantisation and Urbanisation}

By the year 2000, there were twice as many peasants in the world as there were in 1900 (as an effect of the four-fold overall demographic growth), but there has since been an absolute decline in the number of peasants in many countries of the Global South $[17,18]$. In addition, there have been new international peasant movements formed, such as the Via Campesina founded in 1993. However, what Araghi [15] termed "global depeasantisation" meant the experience being lived by an increasing number of people involved in agriculture who had direct access to the production of their means of subsistence and who were becoming rapidly and massively concentrated in urban locations. In 1950, only $29 \%$ of the total world population lived in urban areas [15]. In 2007, for the first time in human history, the majority of the world's population lived in cities [1]. 
What was explained as the elimination of inefficient producers by the market's invisible hand in the World Bank's World Development Report 2008: Agriculture for development, shows its "visible foot, "as Araghi [19] puts it, in "state policies that dismantle social welfare systems, deregulate land markets, remove import controls and food subsidies, impose agro-exporting regimes, and expose millions of petty agrarian producers in the South to compete with heavily subsidised transnational food corporations and highly capitalised agricultural producers in the North." The "visible foot" is also shown in the population displacement induced by the enclosure of resources and territories, and in the preferential treatment of urban sectors by governments [20].

Spatially, global depeasantisation is characterised by: global deruralisation, evidenced in part by the increasing presence of industrial, agro-commercial, information, and service economies in former rural spaces, invasion by infrastructure, expansion of enclosed suburbia, and depopulation, and over-urbanisation, demonstrated by the peripheral expansion of urban space via the massive concentration of people and activities into urban centres [15]. These phenomena are reflective of a pattern of differentiation of geographical space. Conceptualised as "a dialectic of implosion/explosion whereby demographic agglomeration in cities evolves in parallel with the aggressive projection of infrastructures and built environments across the non-urban realm", the notion of "planetary urbanisation" has been gaining increasing attention in the field of urban studies [2]. The non-urban realm should not be interpreted simply as an external entity that serves to demarcate the urban condition from its supposedly rural "other" - thinking of the urban space as territorially, socio-economically, or environmentally self-contained does not make any sense [21]. The rural-urban dichotomy has divided knowledge since it assumes that economic, social and political processes that are present in both spaces are dissociated [11]. The urban space represents an increasingly global fabric in which the socio-cultural and political-economic relations of capitalism are enmeshed [22]. The non-urban space has been largely internalised within an uneven yet globally relevant process of urbanisation.

In the modern city, nature is turned into urban space through commodification, which is understood as the social and cultural process of inserting socially metabolised goods (water, energy, waste, food) into market relations. Kaika and Swyngedouw [6] explained that "accompanied by a process of fetishisation, the socioenvironmental process of the production of the city is blurred and banned from everyday consciousness". The "urban fetish" supports and enacts, both materially and culturally, an ideology of progress, wherein technology and urban infrastructure networks in themselves imply emancipation. This is reflected in urbanisation policies, such as the New Urban Agenda adopted at Habitat III [16], which sets a framework for the promotion of "sustainable urbanisation". The Agenda identifies cities as the engines for sustainable and inclusive economic growth, social and cultural development, and environmental protection. The "urban age" [22] is assumed not only to be irreversible but also beneficial.

The increasing importance of the state's role as a facilitator of growth and promoter of urban environments reflects a long-standing industrial and urban bias in development [13,23]. Nevertheless, the contradictions and tensions of capitalist modernisation increasingly reveal that technological innovation and progress, although indeed delivering the promised material in the form of commodified goods, somehow fail to deliver a better or non-conflictive society. The invisible production of the city materialises in the form of accumulated waste, dirty water, pollution, and social disintegration [6].

\subsection{The Social Metabolism of Mexico City's Conurbation}

Capitalist urbanisation is only possible through multiple socio-ecological processes of domination/ subordination and exploitation/repression, making the socioenvironmental metabolism of cities stretch from their immediate environments to the most remote corners of the planet [6,21]. In the case of Mexico City's conurbation, its energy consumption increased from 443 petajoules (PJ) in 1990 to over $700 \mathrm{PJ}$ in 2010 (almost 17 million toe), primarily depending on fossil fuels extracted mainly from oil reserves in the Gulf of Mexico (A Petajoule is equivalent to 23,884 tons of oil equivalent, toe. Nowadays, the northern territory of Mexico is being menaced by the use of "fracking" techniques.). In terms of 
water, despite importing one-third of the overall water consumed from two neighbouring basins with points of extraction situated more than 100 kilometres away, the Mexican capital still suffers from high water stress [21]. The population density of Mexico City (as is the case in many other cities as well) makes it necessarily dependent on the hinterland and even on distant territories for its social metabolism, both as inputs and for waste disposal.

The surrounding agricultural area of the metropolitan area is an integral part of the city for the provision of food, clean air, and other resources, and as a reservoir for water. However, smallholder peasants have been universally stigmatised as unproductive actors on the grounds that they use too much labour, do not produce a large surplus for the market, and do not make scientific, and rational economic decisions about production and innovation [20]. An economic conflict arises over the appropriation of the potential differential rents of the preserved green spaces as they are consumed by urban sprawl, and previously unaccounted negative environmental effects appear [24]. This is sometimes evidenced in the emergence of socio-environmental conflicts that are directly related to urbanisation (see Table 1 for the nine cases selected for our study).

Table 1. List of case studies, their descriptions, type of conflict, type of property, the status of the project (2019), link to the Environmental Justice Atlas (EJAtlas) database. (Created by the authors with information of the EJAtlas).

\begin{tabular}{|c|c|c|c|c|c|c|}
\hline ID & Case & Description & $\begin{array}{l}\text { Type of } \\
\text { Conflict }\end{array}$ & $\begin{array}{c}\text { Type of } \\
\text { Property }\end{array}$ & Status of the Project & Link \\
\hline 1 & $\begin{array}{l}\text { Cerro de la } \\
\text { Tortuga }\end{array}$ & $\begin{array}{l}\text { The community of Tetelpa rises in defence of } \\
\text { the Cerro de la Tortuga against the real estate } \\
\text { development intended by Casas GEO. }\end{array}$ & $\begin{array}{l}\text { Social } \\
\text { housing } \\
\text { project }\end{array}$ & $\begin{array}{l}\text { Natural } \\
\text { conservancy } \\
\text { land }\end{array}$ & $\begin{array}{l}\text { Cancelled; the territory } \\
\text { was declared a Natural } \\
\text { Protected Area (NPA). }\end{array}$ & $\begin{array}{l}\text { https: } \\
\text { //ejatlas.org/conflict/ } \\
\text { casas-geo-en-el- } \\
\text { cerro-de-la-tortuga }\end{array}$ \\
\hline 2 & La Ciénega & $\begin{array}{l}\text { In } 2003-06 \text { the municipal administration of } \\
\text { Tepetzingo, Emiliano Zapata, Morelos, } \\
\text { authorised building a social housing project of } \\
15,000 \text { units which threatened the water } \\
\text { supply of } 13 \text { villages. Roads were blocked, } \\
\text { protestors were jailed. }\end{array}$ & $\begin{array}{l}\text { Social } \\
\text { housing } \\
\text { project }\end{array}$ & $\begin{array}{l}\text { Natural } \\
\text { conservancy } \\
\text { land }\end{array}$ & $\begin{array}{l}\text { Cancelled; the territory } \\
\text { was declared an NPA. }\end{array}$ & $\begin{array}{l}\text { https://ejatlas.org/ } \\
\text { conflict/unidad- } \\
\text { habitacional-la- } \\
\text { cienega }\end{array}$ \\
\hline 3 & Metro Tláhuac & $\begin{array}{l}\text { In } 2007 \text {, the project of a new subway line (12) } \\
\text { is presented as part of an urbanising project of } \\
\text { the Tláhuac district in Mexico City. Ejidatarios } \\
\text { were dispossessed of their land. }\end{array}$ & $\begin{array}{l}\text { Infrastructure } \\
\text { for domestic } \\
\text { mobility }\end{array}$ & Ejidal land & $\begin{array}{l}\text { Constructed and } \\
\text { operating. }\end{array}$ & $\begin{array}{l}\text { https://ejatlas.org/ } \\
\text { conflict/linea-12- } \\
\text { del-metro-tlahuac }\end{array}$ \\
\hline 4 & Arco Sur & $\begin{array}{l}\text { A new project for a } 235 \mathrm{~km} \text { road to the south } \\
\text { of Mexico City connecting with Morelos and } \\
\text { Puebla was born in } 2010 \text {, the so-called Arco } \\
\text { Sur. It would be built on communal lands and } \\
\text { protected natural areas. The opposition } \\
\text { stopped the project. }\end{array}$ & $\begin{array}{l}\text { Infrastructure } \\
\text { for domestic } \\
\text { mobility }\end{array}$ & $\begin{array}{l}\text { Communal } \\
\text { land }\end{array}$ & Cancelled & $\begin{array}{l}\text { https: } \\
\text { //ejatlas.org/conflict/ } \\
\text { arco-sur-milpa-alta }\end{array}$ \\
\hline 5 & Arco Poniente & $\begin{array}{l}\text { A } 42 \mathrm{~km} \text { highway in Puebla, destroys an } \\
\text { agricultural area and deprives many farmers } \\
\text { and landless peasants of livelihood. Leaders } \\
\text { of resistance, such as Abraham Cordero were } \\
\text { imprisoned. }\end{array}$ & $\begin{array}{l}\text { Infrastructure } \\
\text { for domestic } \\
\text { mobility }\end{array}$ & Ejidal land & $\begin{array}{l}\text { Constructed and } \\
\text { operating. }\end{array}$ & $\begin{array}{l}\text { https: } \\
\text { //ejatlas.org/conflict/ } \\
\text { arco-poniente }\end{array}$ \\
\hline 6 & $\begin{array}{l}\text { The road La } \\
\text { Pera-Cuautla }\end{array}$ & $\begin{array}{l}\text { Frentes Unidos en Defensa de Tepoztlán tried } \\
\text { to stop the widening of the road which } \\
\text { implied land grabbing and irreversible } \\
\text { impacts on a protected natural area. }\end{array}$ & $\begin{array}{l}\text { Infrastructure } \\
\text { for domestic } \\
\text { mobility }\end{array}$ & $\begin{array}{l}\text { Communal } \\
\text { and ejidal } \\
\text { land }\end{array}$ & Under construction. & $\begin{array}{l}\text { https://ejatlas.org/ } \\
\text { conflict/ampliacion- } \\
\text { de-carretera-en- } \\
\text { tepoztlan-mexico }\end{array}$ \\
\hline 7 & $\begin{array}{l}\text { The road } \\
\text { Toluca-Naucalpan }\end{array}$ & $\begin{array}{l}\text { Resistance since } 2007 \text { by an Otomí community } \\
\text { near Mexico City against a four-lane } \\
\text { motorway (Naucalpan-Toluca) that would cut } \\
\text { across their sacred territory and forest. }\end{array}$ & $\begin{array}{l}\text { Infrastructure } \\
\text { for domestic } \\
\text { mobility }\end{array}$ & $\begin{array}{l}\text { Communal } \\
\text { land }\end{array}$ & $\begin{array}{l}\text { The project was } \\
\text { modified to incorporate } \\
\text { tunnels and bridges for } \\
\text { wildlife and human } \\
\text { crossing and is now } \\
\text { under construction. }\end{array}$ & $\begin{array}{l}\text { https: } \\
\text { //ejatlas.org/conflict/ } \\
\text { xochicuautla- } \\
\text { comunidadotomi- } \\
\text { mexico }\end{array}$ \\
\hline 8 & $\begin{array}{l}\text { Circuito Exterior } \\
\text { Mexiquense }\end{array}$ & $\begin{array}{l}\text { Ejidatarios protest against OHL for pending } \\
\text { compensations for the land used for the } \\
\text { construction of the Circuito Exterior } \\
\text { Mexiquense, which links Mexico City's radial } \\
\text { highways. }\end{array}$ & $\begin{array}{l}\text { Infrastructure } \\
\text { for domestic } \\
\text { mobility }\end{array}$ & Ejidal land & $\begin{array}{l}\text { Constructed and } \\
\text { operating. }\end{array}$ & $\begin{array}{l}\text { https: } \\
\text { //ejatlas.org/conflict/ } \\
\text { circuito-exterior- } \\
\text { mexiquense }\end{array}$ \\
\hline 9 & $\begin{array}{l}\text { New } \\
\text { International } \\
\text { Airport in } \\
\text { Atenco } \\
\text { (NAIM-Atenco) }\end{array}$ & $\begin{array}{l}\text { In 2006, there was strong repression in San } \\
\text { Salvador Atenco against the Frente de Pueblos } \\
\text { en Defensa de la Tierra which opposed the } \\
\text { expropriation of their land for the construction } \\
\text { of Mexico City's new airport. The resistance } \\
\text { managed to put the project on hold until on } \\
\text { 2017, the presidential administration of } \\
\text { Enrique Peña Nieto relaunched the project. } \\
\text { In 2018, after a public consultation, the project } \\
\text { was cancelled by the recently elected } \\
\text { president AMLO. }\end{array}$ & $\begin{array}{l}\text { Infrastructure } \\
\text { for } \\
\text { international } \\
\text { mobility }\end{array}$ & Ejidal land & $\begin{array}{l}\text { Cancelled. A new } \\
\text { airport has been } \\
\text { proposed for another } \\
\text { location. }\end{array}$ & $\begin{array}{l}\text { https: } \\
\text { //ejatlas.org/conflict/ } \\
\text { actualisacion- } \\
\text { atenco-aeropuerto- } \\
\text { internacional- } \\
\text { mexico }\end{array}$ \\
\hline
\end{tabular}




\subsection{Urbanisation and the War against Peasantry in Central Mexico}

The urban area of Mexico City covered 378 hectares in 1824 and grew relatively slowly until the end of the XIX century. After the Mexican Revolution, due to the national industrialisation agenda and the federal government's decision to concentrate a great part of this activity in Mexico City, accelerated population growth and urbanisation of the Mexican capital was triggered. The urban sprawl reached districts of the State of Mexico and Hidalgo. With these urbanised areas, the Metropolitan Area of the Valley of Mexico (ZMVM) was created [25]. Today, the ZMVM has more than 20 million inhabitants, equivalent to $17 \%$ of the national population, in an area that represents less than $1 \%$ of the national territory. Although the population growth has slowed, it still averaged $1.2 \%$ annually throughout the last decade, with peripheral areas growing faster than the urban core [26]. Despite the urban sprawl, the density of the metropolitan area has not decreased, maintaining a density of 13500 inhabitants per square kilometre, i.e., 135 inhabitants per hectare [26].

In this expansive process of industrialisation and urbanisation, many of the territories that once belonged to indigenous and peasant communities were devoured. Between 1950 and 1970, most urban growth took place on ejidal lands (The system of ejidos is the result of the Mexican peasant movement that asked for the restitution of their lands. The ejido refers to an area of agricultural land, on which ejidatarios individually farm designated parcels and collectively maintain communal holdings. The institutionalisation of the peasant movement gave rise to the creation of the ejido with a corporate structure which defined the ejidal core (a group of ejidatarios) and not the individual peasants, as owners [9]. Ejidos differ from communal land, a type of property also legally recognised by the Mexican state, in that the latter is not individually parcelled, and it has a more historical character.); for the 70 s, $27 \%$ of the total urban growth took place on ejidal and communal territory (communal land signified 3\%); for the 80s, the tendency of the previous decade consolidates [12]. This did not mean that urbanisation stopped on ejidal land, on the contrary, in the 80s, the extension of urbanised ejidal territory grew almost $100 \%$, whereas, in the State of Mexico, urbanisation of ejidos tripled (although urbanised private property grew four times more) [12]. For the 90s, tendencies changed radically-most of the urbanisation took place on communal land.

This phenomenon is also typical through the whole region of Central Mexico. In Cuernavaca, Morelos, the event that radically changed the landscape was the construction of the Industrial City of the Valley of Cuernavaca in the neighbouring district of Jiutepec. The industrial area attracted thousands of migrants from the neighbouring states seeking a place to live and inaugurated a phase of constant invasions and illegal occupations of communal and ejidal properties. This also created a growing real estate market that put pressure on agricultural land [27]. This not only signified the loss of ecological conservation land but also the privatisation and marketisation of social property and its associated livelihoods [25]. The incorporation of social property in urban development continues to feed the irregular growth of cities, as well as the type of expansive growth promoted under "urban planning" programs [28].

Irregular settlements are signalled as the main engine of the city's growth and expansion. Homelessness and the lack of policies oriented toward guaranteeing the right to housing explain why many search for informal methods of providing themselves with a house via the illegal acquisition of land [25]. The national institutions responsible for providing housing transformed themselves into entities who simply provide credits, leaving the production of housing to large real estate companies and the financing to intermediaries [27]. In the context of neoliberal globalisation, those who represent real estate development and commercial and financial capital greatly influenced urban management. These actors have been supported by the state in the deregulation of laws that obstruct the commercialisation of ejidos and communal property, such as the modification to article 27 of the Mexican Constitution made by the ex-president Salinas in 1992, and in the creation of procedures that facilitate their incorporation to cities [12]. The state has also enabled changes to the forms of ownership, use, and occupation of land (i.e., from residential to commercial, from agricultural to urban, from public and social to private, from ecological to urban) [25]. The use of land for urbanisation is one of 
the most important commercial activities in Mexico and is developed by private and public organisms. The high revenues obtained also enhance the corruption of urban planning [27].

The Survival and Recreation of the Rural Identity

Studies that analyse urban expansion have mainly prioritised urban indicators, such as the demographic dynamic or the nearness to urban infrastructure, which prove that the ZMVM is incorporating surrounding territories. Little attention has been put on those variables that would help characterise some aspects of the rural dynamics, for instance, the proportion of the agrarian activity in all economic sectors [10]. In this context, many localities that are considered urban have an important presence of rural population, making it hard to define whether they have an urban or agrarian profile. The blurring of these frontiers has a decisive impact on the conceptions regarding rural and urban identities; urbanisation could be a process that generates new spaces but also identities that contain new forms of relationships between the urban and the rural [10].

According to Cruz's studies on peri-urban urbanisation [11], although industrialisation has modified the rural population's behaviour by offering employment on secondary activities, this phenomenon has not determined the disappearance of agricultural work. She states that their integration to the urban lifestyle and cultural models reworks the peasant tradition, rather than supposing a rupture with it. In this sense, the peasant unit counts with new ways to get resources while continuing with subsistence agrarian activities, enabling the reproduction and recreation of the peasant identity [11]. In this regard, she states that the depeasantisation process has been interrupted as peri-urban peasants (ejidatarios particularly), search to continue with agricultural work by keeping their plot of land since it is recognised as a valuable resource that can satisfy the needs of the family unit in response to the economic crisis. She also states in a more recent study [13] that urbanisation cannot be considered as a hegemonic process free from contradictions; the conformation of new urban spaces is a product of the close relationship between economic and social practices derived from local, national, and worldwide interests. Generally, this relationship is conflictive, and in many cases, it structures itself as a local opposition and resistance to neoliberal urban projects (megaprojects) [13].

\subsection{Methodology}

In order to shed light upon the local particularities that redirect or reinforce urban development, a multiple case study was carried out for this investigation. Following Paz's revision [29] of 133 socio-environmental conflicts in Mexico reported by the national media between 2009 and 2012, we selected the most relevant cases, based on the information available, in which an agrarian community resisted the installation of city enterprises or infrastructure. Five cases were taken from the mentioned work, and four more recent conflicts that were reported by the national media as well were also included. Of the nine case studies, two involved projects of real estate development, specifically the two social housing projects of (1) "La Ciénega" and (2) Casas GEO's in the natural area "Cerro de la Tortuga", both in the state of Morelos. Six of the case studies involved infrastructure for domestic mobility: (3) the extension of a subway line "Metro Tláhuac" in Mexico City and the construction of highways; (4) the "Arco Sur" in Milpa Alta in Mexico City; (5) the "Arco Poniente" in the state of Puebla; (6) the Tepoztlán road "La Pera-Cuatla" in the state of Morelos; (7) the "Toluca-Naucalpan" in Xochicuautla, State of Mexico; and (8) the "Circuito Exterior Mexiquense" that runs through the State of Mexico and links Mexico City's radial highways. One case involved infrastructure for international mobility, namely (9) the New International Airport (NAIM) in Atenco, State of Mexico (see Figure 1 and Table 1). 


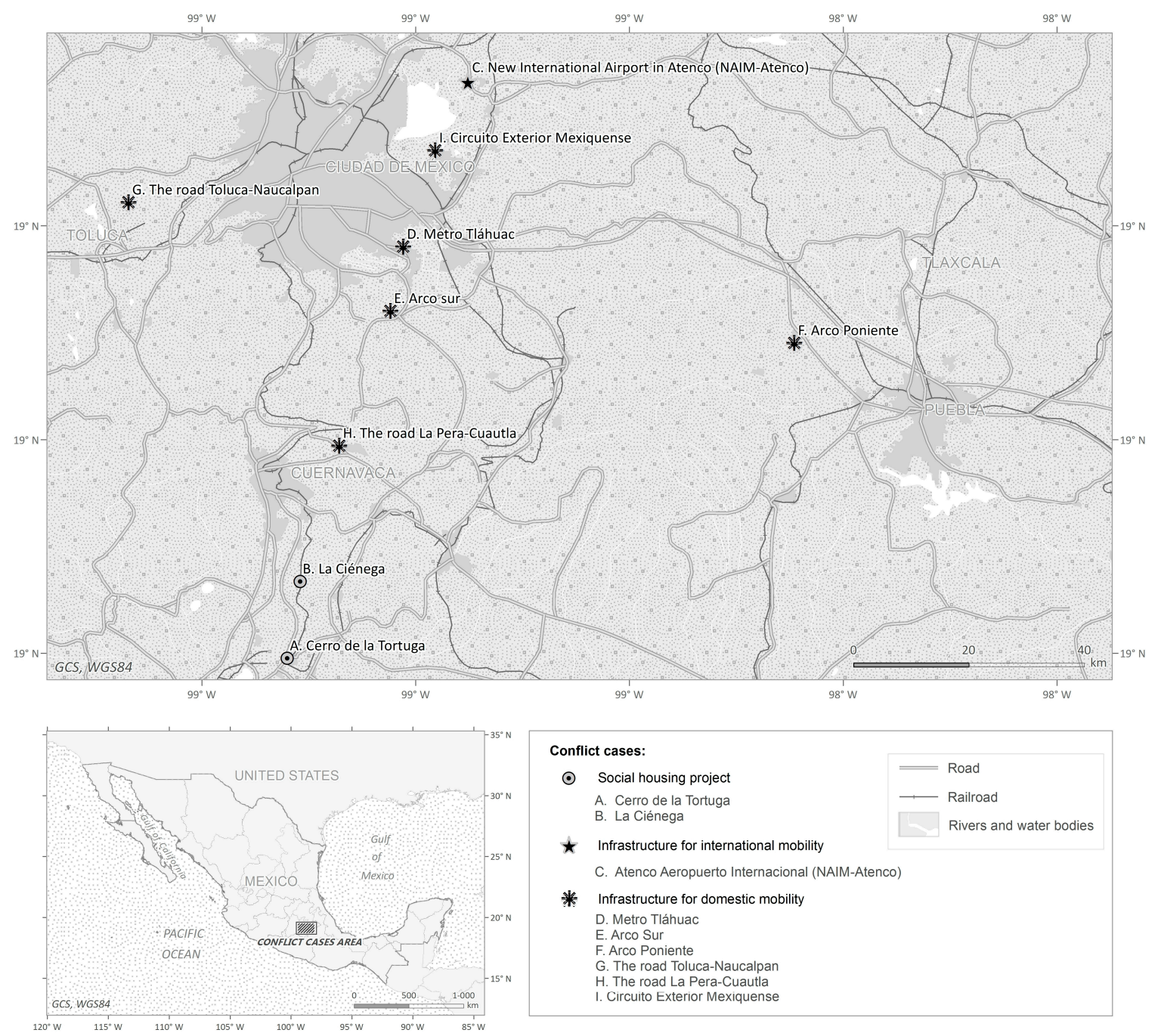

Figure 1. The allocation of environmental conflicts analysed related to the infrastructure for domestic and international mobility and social housing. Data sources: conflict cases-Environmental Justice Atlas ICTA-UAB, CC BY-NC-SA 3.0 ES (www.ejatlas.org); administrative areas (https://www.gadm. org) - GADM database of Global Administrative Areas; inland water, roads and railroads—Digital Chart of the World (https://worldmap.harvard.edu/data/geonode:Digital_Chart_of_the_World); urban areas-Geofabrik GmbH, CC BY-SA 2.0 (http://download.geofabrik.de).

The Environmental Justice Atlas (EJAtlas) database of "ecological distribution conflicts" (The database forms in the EJAtlas are in open access (www.ejatlas.org) after a process of "moderation" which was carried out at the ICTA-UAB.) served as the tool for documenting our nine Mexican conurbation cases. Therefore, in this paper, the many references contained (under Sources and References) in the database forms in the EJAtlas are not listed. The EJAtlas acknowledges the plurality of legitimate perspectives and uses a comparative framework with the analytical goal of identifying patterns and relationships between forms of mobilisation, outcomes of conflict cases, and the social actors' perspectives [30]. Based on secondary data, namely national press, blogs, community manifestos, documentaries, academic research, and NGO reports, we developed the individual cases focusing mainly on the following categories of the EJAtlas: source of conflict, actors involved, project justification, arguments against the project related to environmental, health and socio-economic impacts, the alternatives to the project presented by the groups mobilising, state facilitation and corruption practices, and outcomes of the conflict. 
In order to discuss the relationship between the expansion of the urban space and the systematic assault on surviving agrarian modes of existence in Central Mexico, the analysis of environmental conflicts focused on:

- understanding how urban expansion transforms the territory, by describing the main infrastructure projects involved as well as their promotional discourses;

- recognising the ways in which expansion of the city affects peasants, by looking at the valuation languages or arguments against the projects and their visible or potential environmental, health, and socio-economic impacts;

- $\quad$ pinpointing the development strategies that are being disregarded, by looking at the alternatives proposed by the mobilised resistance;

- identifying the role of the state and economic interests in the implementation of such projects, by looking at facilitation by the state, corruption and repression, and criminalisation practices;

- assessing the consequences and productivity of the social movements by looking at the actors involved and the outcomes of the conflicts in terms of success or failure under the lens of environmental justice.

\section{Results}

Urbanisation transforms space primarily, but not exclusively, through the built environment and infrastructure. Different expressions of the physical expansion of the city can be observed, which help us understand what urbanisation looks like at the urban frontier (see Figure 1 and Table 1). The cases of La Ciénega and Cerro de la Tortuga consist of real estate development projects of 2000 and 7000 social-interest houses, respectively, to be constructed on natural conservancy lands surrounding the urban area of the state of Morelos. Other expressions of the territorial gain of the city can be found in the expansion of its urban infrastructure. This is seen in the case of the extension of the Metro Tláhuac subway line to Milpa Alta, wherein 20 new subway stations and a new terminal which included a commercial centre were built on one of the few rural areas remaining within Mexico City. Another expression was seen in the ambitious federal project of the New International Airport which was planned for construction on 5000 ha of the Texcoco wetland in the State of Mexico. Also characteristic of the expansion of the city is the construction of highways, freeways, and roads (which contributes to conurbation (A derogatory term coined by Patrick Geddes in 1915 -nowadays often used neutrally- to describe "a region comprising a number of cities, large towns, and other urban areas that, through population growth and physical expansion, have merged to form one continuous industrial built-up environment. In most cases, a conurbation is a polycentric urbanised area, in which transportation has developed to link areas to create a single urban labour market or travel to work area" [31].)). The Arco Sur, the Arco Poniente, the Tepoztlán road La Pera-Cuatla, the Toluca-Naucalpan, and the Circuito Exterior Mexiquense are five of many highway projects that make up the outer ring of the ZMVM and which are meant to interconnect the city with the southern, eastern, and western regions of the country. The Arco Sur would privatise transit through communal land and the Natural Protected Areas of Xochimilco, Tlalpan, and Milpa Alta in Mexico City, while the Arco Poniente would do the same in nine agricultural entities in the state of Puebla. In the state of Morelos, this process is mirrored with the Tepoztlán road La Pera-Cuautla, and in the State of Mexico with the Circuito Exterior Mexiquense. Similarly, the Toluca-Naucalpan highway cuts across the sacred territory and forest of Xochicuautla and two other indigenous communities of the State of Mexico.

All nine conflicts take place in marginalised, although certainly not silent communities and projects were mostly passed off as investments favouring national, regional, or community development. In real estate development cases, it is seen that the justification of the project was to provide affordable housing to low-income people. In regard to the highway projects, a desire to create better connections between the country's economically powerful regions of the centre and south becomes evident. A similar objective was found behind the subway line extension to Milpa Alta when it was argued that because 
of its remoteness, that part of the capital had been denied investment and had become a "dormitory city". The subway line would enable more economic activity and improve the transportation of people from the east and south-east areas of the capital to the city centre. In the case of the New International Airport, it was argued that the currently operating airport is too small, and the reasons given for the construction of a new one included generation of jobs, increases in investment, higher productivity, strengthening of the business environment, and equilibrated regional development [32]. All projects seem to respond to a neoliberal development agenda and sum up to a total investment of around thirteen billion dollars.

\subsection{Values in Dispute}

Why are these "well-intentioned" development projects causing social unrest within the peasant localities wherein they were proposed or implemented? As declared in their manifesto, the "13 Villages of Morelos movement" argued that the urbanisation (La Ciénega) imposed by companies and the government-by qualifying their land as unproductive despite the existence of peasants and indigenous people still cultivating it-was designed to sell development and modernisation ideas that respond to the interests of the powerful at the expense of increased misery within the communities. They said that "through urban growth, savage tourism, modern industries, and industrial agriculture, local governments apply the general federal policy; systematically destroy the peasantry to absorb traditional communities in cities, or drive them out by migration in order to privately appropriate their natural resources" [33]. Likewise, in the fight against the construction of the Arco Sur highway, inhabitants of Milpa Alta protested against a project that entails "the decapitalisation of agriculture, the expulsion of the rural population to urban areas and the United States, and land dispossession" [34]. Correspondingly, the leader of the peasant mobilisation in Puebla stated that the Arco Poniente highway "implicates the risk of overexploitation of water and other natural resources, the development of housing projects and commercial centres beside the highway, and the homogenisation of communities" [35].

One recurrent argument against the expanding city projects given by peasants concerned land dispossession. Ejidatarios from San Salvador Atenco and Texcoco protested against the airport, from Tláhuac resisted the extension of the subway line in their lands, from the State of Mexico fought against the Circuito Exterior Mexiquense, from the state of Puebla fought against the construction of the Arco Poniente highway, and peasants from Milpa Alta struggled against the Arco Sur highway, all highlighting the agricultural land-grabbing that urban projects bring about, endangering the income and food security of many families. For example, the Arco Poniente would affect 244 ha of agricultural land belonging to 1200 ejidatarios. Apart from subsistence agriculture, peasants also produce 1500 tonnes of vegetables and legumes that are consumed throughout the central regions of the country.

Resistance was also due to previous experiences of the communities; wherein development projects often resulted in land expropriation without only compensation. This was true in the subway line extension case, where some of Tláhuac's ejidatarios were not compensated. In the case of the Circuito Exterior Mexiquense, ejidatarios from the State of Mexico could not stop the construction of the highway and felt defrauded for the low compensation received for their land. The $154.9 \mathrm{~km}$ highway cuts through 18 municipalities of the State of Mexico, linking the radial highways of "México-Querétaro", "México-Pachuca", "Peñón-Texcoco", and "México-Puebla", and ending at the frontier with the state of Morelos. In 2010, when the highway was under construction, peasants from the Cuautlalpan, Montecillo, and Coatlichán ejidos blocked the entrance to the construction site, claiming debts. One year later, a protest was carried out by numerous ejidatarios from Chimalhuacán, claiming that the highway had imprisoned and disconnected them. Today they must follow an extensive detour to pass from one side of the municipality to the other. One of the leaders stated: “We don't like the condescending way by which businessmen treat us. First, they convince our smallholders to sell at a very low price-at less than three dollars per square metre. Nowadays, the toll fee per car is higher than that amount." 
Impacts regarding water are also very common. Peasant communities claim that the construction of houses, highways, or any other type of urban infrastructure in areas of groundwater recharge drastically diminishes water availability. In the real estate development of La Ciénega, a study made by the Autonomous University of the State of Morelos (UAEM) concluded that the project would limit water supply to 100000 inhabitants, leave 12 communities without water for agriculture and that the discharge would pollute the water used for irrigation [36]. Similarities could be found with the case of defence of the Cerro de la Tortuga, which is part of an important region of the high-biodiversity forest, an ecological niche for a diverse number of animals such as the jaguar, white-tailed deer, wild rabbit, and many birds and bats, and one of the lungs of the central-southern region of the state of Morelos. A lack of water was already present in the region, and the real estate development would leave Tetelpa (the planned location for the project) and other nearby communities without water. Protesters also argued that the new houses would affect the Apatlaco river through their drainage systems, thereby impacting the villagers who use it for agricultural or domestic needs.

In relation to the dispossession of agricultural land, peasant communities highlight the role of these spaces as water catchment areas. This was argued in the case of the Arco Sur highway and in the extension of the subway line to the rural areas of Tláhuac and Milpa Alta in Mexico City, where the construction of the last five stations would annihilate the lake area of the region and affect water availability for inhabitants of the southern and eastern parts of the Mexican capital. These communities are the last rural areas of the city, producing $80 \%$ of the nopal in Mexico and conforming the biological corridor of the Mexican capital. They provide $30 \%$ of the water consumed within Mexico City [37]. Moreover, the primary roads that interconnect the new subway terminal cross the wetland area beside the Tláhuac lagoon, the destination for twenty thousand migratory birds every winter. In a similar way, the Xochicuautla (Toluca-Naucalpan) highway would pass between the Chignahuapan and Chimaliapan lagoons that are part of a natural protected area, blocking the water runoff and transitory bird routes between the two lagoons. Correspondingly, in the case of the airport, the area of the Texcoco Lake would be seriously affected. This area is considered to be an important zone for the conservation of birds, meeting all the requirements considered for the Ramsar Convention on Wetlands of International Importance. Moreover, it is a priority hydrological natural area for its key function as a regulation vessel that prevents flooding in the region. Not only will the project provoke more flooding, but access to drinking water for the population of the ZMVM would be put at risk. This means that health, food security, and decent living for the affected communities and inhabitants of Mexico City are put at risk by the impacts of urbanisation on water resources.

A secondary effect of urbanisation, namely bringing more urbanisation, is also mentioned by peasant communities. The 13 Villages of Morelos movement against La Ciénega project claimed that housing units are usually accompanied by commercial centres, highways, gas stations, and other urban infrastructure which accelerate environmental deterioration and compromise the organisation of the communities. This is exemplified by the realisation that the planned housing unit would lead to a $400 \%$ increase in the population of Tepetzingo (the locality where the project would take place) [38]. Likewise, the real estate development in the Cerro de la Tortuga was contemplated for 28000 inhabitants, whereas Tetelpa's population is less than 5000 people. Taking the stance that these projects do not solve the housing needs of the communities since peasants rarely have the money to buy the houses despite their "social" character, real estate developments open a new need for new urban infrastructure that is required in order to supply basic services to the incoming population. This argument is also relevant for projects not involving real estate developments. For example, peasants resisting the extension of the subway line to their communities refer to the expansion as the access which enables expansion of the urban area. The refusal to sell their land is to avoid deforestation and the irregular growth of the city. Likewise, peasants of the state of Puebla mention that there is a risk of housing projects and commercial centres being developed beside the Arco Poniente highway, and see it as an assault against their communal food production and lifestyle. 
Water and land dispossession and degradation not only impact aspects of the environment, health, and socio-economic activities in communities, but also have an effect on their identities as well. An example is the community of Xoxocotla, leader of the 13 Villages of the Morelos movement. Water is seen not just as a vital condition of existence in Xoxocotla, but also as a fundamental social institution of their villages since its supply is a result of communal work done by their grandparents in building the infrastructure to bring water from the nearby Chihuahuita spring [39]. Water also occupies a central place in the regional cosmovision, a factor that contributed to the movement's social power. The 13 Villages of the Morelos movement were also involved in the defence of the Cerro de la Tortuga. This struggle had sacred implications as well, as the area contains tlahuican archaeological vestiges and is a space where annual ceremonies are celebrated. Other examples are the cases of Milpa Alta, and Xochicuautla's struggle against the highways that would slice their communities in half, limiting their access to the forest and affecting nahua and otomi traditions, respectively.

Further, the organisation of a community can be affected by the way in which the projects are implemented. All of the conflicts reveal a lack of consultation with the communities where the urbanisation initiatives take place, completely ignoring the fact that communities had gathered in assemblies (a right acknowledged in the Mexican agrarian law, in which all decisions regarding their property are made and where all the community participates in a horizontal manner) to analyse the infrastructure projects proposed for their territory. Such was the case with the community of Xochicuautla, who through these assemblies determined that the Toluca-Naucalpan highway could not pass through their territory and Sacred Forest. They also decided to present themselves not as an agrarian community but as an indigenous community, hoping, albeit unsuccessfully, to receive more legal defence. In the case of the New International Airport, Atenco peasants argued that an illegal mechanism was implemented by carrying out simulated ejidatarios' assemblies with people pretending to be farmers, where the disincorporation of land from communal use was approved in order to transform it into private property. This illegal mechanism, which was found to have been used in other cases as well, fragments the internal social fabric.

Different opportunities are also being overlooked by promoting development only through urbanisation. The 13 Villages of Morelos movement, when gathered in a congress in 2007, showed a desire to incorporate themselves into the "solidarity economy" and fair trade and organic product networks. Other proposals along the same line included the promotion of organic tianguis commerce to reduce waste, the creation of an inventory of the fields with GMO crops to develop a strategy against genetic contamination, the creation of a seed bank, and the development of an environmental education program. Natural conservation was also present in Morelos communities' alternatives to land urbanisation. A successful example was the case of the Cerro de la Tortuga struggle, where, with the help of the UAEM, peasants suggested that it be declared a Natural Protected Area (NPA).

Similarly, organic agriculture was also mentioned as an alternative in the rural community of Milpa Alta involved in the struggle against the Arco Sur and the subway line. They are recognised for having rejected the installation of supermarkets and convenience stores on communal lands, openly defending their own markets and stores where local products are sold. In the community, food provision is communal; the food supply for the entire community is produced within their territory, and bartering is still practised. In the negotiation meetings before the construction of the subway line, the community suggested to develop a high-productivity organic orchard in that space and to stop the construction of the subway line in the Mexicaltzingo neighbourhood. Another proposal was to build a Metrobus line, the environmental impacts of which would have been much less extensive. Nevertheless, the communities were not listened to and instead were bombarded with useless information such as the size of the screws used to build the subway.

In other cases, such as those concerning real estate developments in the Cerro de la Tortuga and La Ciénega, the negotiation tables completely lacked representatives from the private sector and government with knowledge of the case and a capacity for action or decision. In the struggles against 
the Arco Poniente and the New International Airport (NAIM-Atenco), peasants never managed to establish a negotiation table with the administration promoting the projects.

\subsection{The Role of the State and Economic Interests}

In all of these projects, the state was involved either directly in the proposal of the project, by facilitating it, or by participating in corruption or repression practices. This research shows that urban infrastructure projects are top-down initiatives from federal or local authorities allied with the private sector operating under an economic growth discourse. In this way, Urban Development Programs like that of Tláhuac are approved, where in addition to the subway line extension, a 140 ha polygon was traced for the construction of supermarkets, hospitals, universities, and other urban services. Tláhuac's Urban Development Program also authorised land-use changes for the "Sierra de Santa Catarina", previously for conservancy and now for Mexico City's new projects, including a police academy, a recycling centre, and a prison. The state's power is first put in action when acquiring the land for the projects. In the case of the airport in Atenco, the president at the time, Vicente Fox, decreed the expropriation of land without any prior consultation with the owners. In the fight against the Arco Poniente, people who refused to sell their land for the construction of the highway were threatened with land expropriation. Those defending their land against the subway line extension also suffered from intimidation tactics which included death threats. Due to the crisis and decapitalisation of agriculture, many of the ejidatarios involved in these conflicts did not reject the project in its totality and instead only asked for compensation for their land (some of them were bribed, as in the case of Xochicuautla's struggle against the highway). Therefore, communities were the focus of a strong division process by which authorities tried to appropriate the land in dispute by destroying their social network.

The granting of construction permits without a proper environmental study impact having been carried out or without endorsement by the village also positions the state as a facilitator for the development of this type of projects. In the case of the Cerro de la Tortuga, Zacatepec's city hall gave construction permits to Casas GEO without the community's approval, further overlooking the illegal acquirement of communal land taking place. In the housing unit La Ciénega, it was also argued that the National Water Commission (CONAGUA) often manipulates information to build a water abundance discourse that enables them to authorize well drilling, which re-directed water to industries and new housing units. The state also plays a key role by focusing its solution to the housing problem in Mexico on the promotion of the construction of social housing units of thousands of low-quality houses on what they call "unproductive land".

The presence of corruption was seen in the case of the subway line extension, where only a year and a half had passed since its inauguration when its partial closure was announced because of technical and structural failures. The project was named by the political opposition as "the biggest fraud in Mexico City's history" [40]. The subway failures led to three ex-officials facing judicial proceedings. In 2015, the ejidatarios of Tláhuac submitted a criminal complaint against the capital's governor for influence peddling, abuse of authority, patrimonial and environmental damage, and unexplained enrichment. Corruption practices were also alleged in the case of the New International Airport and the Circuito Exterior Mexiquense. These projects are related to the Atlacomulco Group, a political organisation comprised of powerful political figures within the Institutional Revolutionary Party (PRI) which is suspected of giving massive public contracts to close friends. The Atlacomulco Group is also linked to Grupo Higa, the company responsible for the construction of the highway in Xochicuautla.

Regarding repression and criminalisation of the protests against the projects, the most relevant case was the one known as the "Atenco's slaughter" in the year 2006. After the first failed intent to expropriate land for the construction of the airport, peasants from Texcoco and San Salvador Atenco had already successfully organised themselves in the People's Front in Defence of the Land (FPDT) and involved themselves with other struggles and resistance movements in the region. What started with eviction of flower growers selling their products on the road turned into a large-scale confront 
between the municipal and state police and the Atenco movement. The police operative resulted in two boys being killed, and 207 arrests, 47 of whom were women, of which 26 suffered torture and sexual aggression by the police. Despite all the human rights violations having been documented, the governor of the State of Mexico at the time, Enrique Peña Nieto, said that "the balance of the operation was positive because it lets us reach the objective, which was to re-establish order. Neither the authority nor the population of Atenco could stay hostage to the interests of a group that had violated the law". He also declared that "the fabrication of accusations is a known tactic used by radical groups, and that it could be the case for the women denouncing being raped by the police with the objective of discrediting the government" [41]. The declarations reveal the iron fist with which the state gets rid of any political opposition, which in this case were the peasants defending their territory and livelihoods.

Criminalisation was present in the case of the Arco Poniente highway as well, when the leader of the mobilisation was imprisoned. After his liberation, he revealed that more than 100 restraining orders existed against peasants who oppose the construction of the highway. The peasant fronts of resistance reported that the government of Rafael Moreno Valle utilised power to persecute environmentalists and give away the water and land of the inhabitants of Puebla to foreign capital. Something similar was argued in the case of the Arco Sur highway; after successfully stopping the project in Milpa Alta, the construction of a Navy Base on the ejidatarios' land was announced four years later, by presidential decree without any prior notice. The community said that "the base is a pretext to have a surveillance zone and control the social movements of the area. The army will work in favour of the megaprojects that are already prowling the area" [42]. The community said that this would be the first step in facilitating the imposition of projects such as the Arco Sur, opening up natural conservation lands for urban development.

\subsection{Actors and Productivity of the Socio-Environmental Conflicts}

We find that the groups who tend to mobilise first against urban sprawl infrastructure projects consist of the semi-urban population, whose main economic activities revolve around agriculture. Although not always defending agricultural land (in both real estate development cases, the land use proposed for the territory in dispute was one of conservancy), the peasants resisting the expansion of the city all belong to ejidal or the communal type of properties and organisations. Moreover, the people involved in the mobilisations in Morelos against the social-housing projects, in Milpa Alta against the Arco Sur highway, and in Xochicuautla against the Toluca-Naucalpan highway acknowledged indigenous identities: tlahuica in the cases of Morelos; nahua in Milpa Alta; and otomí in Xochicuautla. Universities also bring the conflict to light through various methods by suggesting the declaration of NPAs, as the UAEM did in the case of the Cerro de la Tortuga; carrying out studies which revealed the unsustainability of the projects, again exemplified by the UAEM when detailing the impacts of the real estate development La Ciénega; and by organising forums where the socio-environmental conflicts are exposed, for example that organised by the Iberoamerican University of Puebla, to which the leader of the Arco Poniente resistance was invited after his release from prison. It is also seen that political opposition parties participate in conflicts either because of a genuine interest in defending the communities raising their voice, or simply with the aim of discrediting the party in power. Their participation usually consists of highlighting impacts, repression practices, and demanding that the government come up with a solution. In 2019, the new president López Obrador, who had been in political opposition to both Fox and Peña Nieto, suspended the construction of the NAIM airport.

Environmental and human rights organisations (both Mexican and international) also often get involved, usually after a strong confrontation between actors has been produced. After the clash between police and the 13 Villages of the Morelos movement in the case of La Ciénega, the Human Rights Commission of the State of Morelos presented a complaint. Also, the Coalition of the Mexican Organisations for the Right to Water, in a letter addressed to Felipe Calderón, the ex-president, demanded respect for the right to protest pacifically, an end to the threats of violence, respect for 
dialogue tables, guarantee for the right to water alongside its protection, and that the access, distribution, and decision-making regarding water be equal across people and regions. Similarly, in the case of the subway line extension, when the people who had resisted leaving their land were evicted, the Human Rights Commission of Mexico City (CDHDF) complained against the excessive use of force by the police. This was also the case for the conflict that arose from the New International Airport project in San Salvador Atenco, where the Inter-American Commission on Human Rights (ICHR), alongside the UN Fund for Women, Amnesty International, and other human rights organisations demanded justice against the Mexican State regarding the "Atenco's slaughter". More than 70 social and environmental organisations which make up the Front against the New Airport and other Megaprojects in the Valley of Mexico also helped articulate the negative impacts of the project once it was re-launched. In the Arco Poniente conflict, local human rights organisations were also present and helped in the liberation of the imprisoned leaders of the resistance to the highway and other related struggles. There were only two cases wherein a human rights organisation made a decisive contribution to stopping the project: that of the Arco Sur highway, where after a complaint was presented by the community representatives at the National Human Rights Commission (CNDH) citing a lack of consultation, the Commission established a reunion with the government entity responsible for communications and transport, and agreed that no highway would be built due to the lack of technical and juridical conditions; and the case of Xochicuautla (Toluca-Naucalpán), wherein the ICHR intervened and the Supreme Indigenous Council's proposal of a technical alternative to the Toluca-Naucalpan highway which was based on tunnels and bridges for human and animal crossing, and which aimed to preserve the water sources of the community, was taken into account.

The actors backing up the projects consist of national (Grupo Higa, Urbasol, Casas GEO, Grupo Carso, ICA, Pinfra, Infraestructura Omega 2000) and international (Alstom and OHL) construction companies, as well as state entities, such as local and federal governments, water commissions and urban planning entities (CONAGUA, State Commission of Water and the Environment; CEAMA), communications and transport entities (Communications and Transport Secretariat; SCT), land banks, and the police. The cases studied seem to be characterised by the invisibility of the private sector, who typically handle everything through intermediaries and who are never present in negotiation meetings. An example can be found in the real estate development planned by Casas GEO. On top of not attending the dialogue tables, they built an alliance with a workers' union of the construction sector, which is known to be affiliated with the PRI, operating as a "clash group", and whose intimidatory practices were reported by the community. Additionally, paid inserts were published in many newspapers of the region and signed by ghost associations but were revealed to be of corporate origin through their drafting, content, and cost. The use of the media was also present in the case of the airport, where a defamation campaign against the Atenco movement preceded the "Atenco's slaughter". The mass media made a public outcry against the "violence of the Atenco macheteros" and demanded "strong action against the criminals altering the social order". A homogenisation of voices asking for the use of force against the Atenco ejidatarios began.

Since all the projects have a public character, construction companies receive a contract, and thus the illegality of land acquisition, the given construction permits, and the implementation of the project lie on the shoulders of the state. Although corporate influence peddling is not easily traced, there have been many allegations of corruption against several of these companies. For example, the construction company ICA was created and grew up under political protection by the PRI political party that exchanged big infrastructure contracts for financial support. With the return of "the new PRI" to the presidential chair, the favouritism for ICA was replaced with that for the Spanish company OHL, which has been at the centre of a scandal for illicit agreements (concessions granted without the proper protocol, financing political campaigns, and inflation of construction budgets) between their Mexican subsidiary and government officials of the State of Mexico, who make up the Atlacomulco Group. The Atlacomulco Group and OHL have been blamed for corruption practices aiming to maintain 
power and enrich themselves, including the construction of the Circuito Exterior Mexiquense and the "Viaducto Bicentenario" highways [43].

Regarding the outcomes of the social movements that arose against urban sprawl projects, it is important to analyse their social and political productivity. This refers to the long-lasting effects that "contribute to the construction of emergent environmental rights and the subjectivities of citizens who hold or pursue such rights" [44]. Of the nine cases, environmental justice was served in four of them through the cancellation of the projects (Table 1): the Arco Sur highway, both of the social-housing projects in Morelos, and in 2018, the cancellation of the International Airport by the new presidential administration after a public consultation was carried out. The conflicts concerning the real estate developments also led to the declaration of the territories in dispute as NPAs.

Despite the formidable strength of urban sprawl, an emancipative movement is revealed. The creation of the 13 Villages of Morelos in defence of water, land, and air movement that participated in both cases in Morelos, and the organisation of ejidatarios and peasants in multiple fronts (Rural Front of the South in Defence of the Land in the case of the subway line extension, the People's Front in Defence of the Land in San Salvador Atenco, and the Peasant Front of Ejidatarios against the Arco Poniente) expose the strengthening of participation of local peasant communities -historically recognised as political actors in Mexico- and reveal a new environmental discourse in their struggles. These organisations are typical of environmentalism of the poor and indigenous [24], which differs from conservation movements.

Despite the inexistence of a regional or metropolitan peasant movement against urbanisation projects, efforts to knit resistances together can be observed. After its birth in 2006, the 13 Villages of Morelos movement adopted other struggles such as other housing units, gas stations, and landfills in Morelos, which became the reason for their involvement in the Cerro de la Tortuga case. Similarly, in a street protest against the subway line extension, peasants from Tláhuac and Milpa Alta received the support of the FPDT from San Salvador Atenco, reaching participation of 5000 farmers. In order to exchange experiences of land defence and to plan collective actions, peasants made calls to other communities, organisations, and civil society, in general, to participate in different types of forums against urban expansion in Mexico. This was the case of the organisation of the first congress of Morelos' communities in defence of water, land, and air wherein a variety of problems were discussed. The congress resulted in the creation of a village council, and a Manifesto was presented. Another example can be found in the participation of the Arco Sur resistance in the Permanent Peoples' Tribunal in the case "Highways and social and environmental devastation" against the Mexican state and companies involved, where it was agreed to create a common space for the fight against highway projects in Mexico. Finally, in the case of the Arco Poniente, a united front resulted from the attendance of different groups resisting the highway and a gas pipeline, namely the "Regional Encounter for the Defence of Natural Resources and Social Rights" in Puebla.

\section{Discussion}

The results shown above illustrate how capitalist urbanisation is only possible through multiple socio-ecological processes of domination/subordination and exploitation/repression as Kaika and Swyngedouw [6] point out. Although it is true that today's indigenous and peasant communities do not live in complete isolation from the capitalist model, urbanisation processes certainly constitute a rupture of their previous livelihood and the insertion into a world with different valuation languages. Urbanisation radically upsets concepts like spaces, time, work, cultural reproduction, social conviviality, relationship with nature, conditions of existence, modes of production, livelihood, identity, and indigeneity. Irregular urban growth, the usual explanation for the expansion of the city which is typically blamed on poor people migrating to the outskirts of the city, sees its counterpart in the urban sprawl that is actually planned with a top-down approach (and sometimes disguised as "green" and "sustainable"), despite the rejection of marginalised but still productive peasant communities. 
Unlike irregular urban growth, where urbanisation is managed by the communities themselves and do not necessarily implicate depeasantisation as Cruz's studies [11] state, neoliberal urbanisation (megaprojects) can definitely be seen as a mechanism by which peasants are being dissociated of their means of production through land and other resources dispossession, evidencing Araghi's thesis [15]. Since there is a scarcity of land available for urbanisation, agricultural land is seen as the reserve that enables future urban projects. Our results confirm the process of fetishisation that accompanies the production of the city [6] - by equating development with economic growth, the flow of capital and goods is prioritised at the expense of environmental, social, and cultural values. A development vision based on efficiency, productivity, and consumption is constructed undemocratically and imposed in an authoritarian manner. Just as Olivera [27], Sánchez, and Díaz-Polanco [25] have discussed, the cases studied show the increasing importance of the state's role as a facilitator of growth and promoter of urban environments.

This paper contributes to urbanisation studies in Mexico by looking in detail at the local particularities that enable the incorporation of agricultural land into the urban space. It has emphasised the existence of peri-urban peasant social movements that do not fight so much for equal infrastructure or access to technological networks, but rather against a type of urbanisation that goes directly against their necessities as communities which are long settled in the territory in dispute. Peasants have been recognised historically, as political actors in Mexico [8,9]. However, the results reveal the incorporation of an environmental discourse to their struggles as a relatively new strategy or concern. Either way, the city - which represents a node of a world economy - faces the same crisis as economic growth itself: its material and energetic unsustainability. Socio-environmental conflicts make visible the territories and cultures that are sacrificed in order to sustain development based on the production of the urban space.

This article shows that the strengthening of the agricultural activities of the ejido and communal sector could represent a form of containment to the expansion of the megalopolis, as Cruz has stated [11]. Agriculture, as an economic activity that satisfies primary needs, human creativity, and promotes the understanding of the nature-human nexus (if agro-ecological practices are prioritised), should be a strategy for socio-ecological change. Agriculture can provide sustainable, satisfying livelihoods for more, not fewer, people. Instead of shedding labour for the non-agricultural economy and promoting migration to the city or internationally, poverty should be taken care of in situ to counter the loss of productive soil, the desertion of productive areas, and the abandonment of resource revalorisation strategies. This is the development pathway that is being ignored and that the peri-urban ejidal and communal social movements make visible. This raises the important question of whether the inhabitants of the city will eventually recognise that the survival of the city itself depends upon the external environments and communities.

\section{Conclusions}

The nine conflicts under study are all very relevant to the growth of Central Mexico's megalopolis. They all surround the Mexican capital, extending its influence beyond the ZMVM, and therefore, producing a conurbation that reaches the states of Mexico, Puebla, and Morelos. They reveal that the city pushes its limits through the built environment, as seen in the construction of real estate developments of thousands of houses and of airports, highways, and other transport infrastructure. Backed by the state through promotion, facilitation, and corruption or repression practices, urbanisation projects respond to a development agenda whose main objective is to push economic growth by opening up new territory for investment. This type of development undermines the very conditions necessary for the existence of the city. Due to the social and environmental impacts on peri-urban peasants with ejidal or communal rights, mobilised resistances rise up. Impacts on peasants include agricultural land dispossession, which has resultant implications in food security and livelihoods. Peasants also highlight the importance of agricultural land for groundwater recharge and argue that urbanisation has extensive repercussions on the quality and quantity of water left available for the 
region, including not only their own communities but the city as well. Dispossession and degradation of natural resources is not the only way in which peasants are affected by the expansion of the city. Peasants also report the danger of losing their economic organisation, cultural identity, and social fabric due to these projects. They contest the paramount value of the type of economic growth which directly opposes their own rights and social values. Sometimes they highlight the ancestral sacredness of some spaces or their pre-historical archaeological value. The struggles of peasant communities against the urbanisation of their territory are not only in defence of their agriculture-based livelihoods; broader ambitions beyond the control and access to resources can be detected.

It is common to think that cities grow in a disorderly and unplanned manner. Nevertheless, urban growth has been promoted by economic and political interests at the expense of peasant communities and neighbourhoods located at the urban frontiers. The communities that are threatened by the expanding conurbation of Central Mexico have close contact with the inputs and outputs of capital. They are the ones who experience the diffuse border of the city. They have been able to put their own history, their own ideas of community, and their importance into a legible perspective. They offer different political and ecological perspectives, despite being deprived of the voice in the mass media (unless they often take spectacular and direct actions, which are still then only seen as anecdotal events). They are the ones evaluating the urgency of the defence of the territory. The complaints from the peasant and indigenous communities inhabiting forests, lakes, and pasturelands surrounding the urban space, have a political meaning: if they succumb to the fate of becoming the chaotic urban neighbourhoods that capital produces, both themselves and the city will be in greater danger of collapsing. They are the ones who, via their defence of land, clean air, and water, help to guarantee the conditions and resources necessary for the survival of the city.

Author Contributions: Conceptualisation, V.R.R., J.M.-A. and S.M.; Funding acquisition, J.M.-A.; Investigation, V.R.R.; Methodology, V.R.R. and S.M.; Supervision, J.M.-A. and S.M.; Writing—original draft, V.R.R.; Writing-review \& editing, J.M.-A. and S.M.

Funding: This research has been possible thanks to the Erasmus Mundus scholarship awarded to Victoria Ruiz Rincón by the European Commission. The authors also acknowledge the support of the European Research Council for the EnvJustice project (GA 695446).

Acknowledgments: The authors thank local and international activists and scholars who collaborate directly or indirectly to the EJAtlas database. We especially thank Marta Borrós for the map design, and Peter Cooper for language revision. We also thank the editors of the Special Issue: "Urban Political Ecology: The Uneven Production of Urban Space and Its Discontents" and the anonymous reviewers for their careful reading of our manuscript and their many insightful comments and suggestions.

Conflicts of Interest: The authors declare no conflict of interest. The funders had no role in the design of the study; in the collection, analyses, or interpretation of data; in the writing of the manuscript, or in the decision to publish the results.

\section{References}

1. United Nations Population Fund (UNFPA). The State of World Population 2007: Unleashing the Potential of Urban Growth; UNFPA: New York, NY, USA, 2007.

2. Brenner, N. Implosions/Explosions: Towards a Study of Planetary Urbanization; Jovis: Berlin, Germany, 2014.

3. Arboleda, M. Spaces of Extraction, Metropolitan Explosions: Planetary Urbanization and the Commodity Boom in Latin America. Int. J. Urb. Reg. Res. 2016, 40, 96-112. [CrossRef]

4. Stephen, B.; Sheelagh, M.; Ken, N.; Beverley, O. The Ecology of a City and Its People: The Case of Hong Kong; ANU Press: Canberra, Australia, 1981.

5. Bettini, V. Elementos de Ecología Urbana; Trotta: Madrid, Spain, 1998.

6. Kaika, M.; Swyngedouw, E. Fetishizing the Modern City. The Phantasmagoria of Urban Technological Networks. Int. J. Urb. Reg. Res. 2000, 24, 124-138. [CrossRef]

7. Robbins, P. Political Ecology. A Critical Introdution; Blackwell: Malden, MA, USA, 2004.

8. Azuela, A. La Ciudad, la Propiedad Privada y el Derecho; Centro de Estudios Demográficos y de Desarrollo Urbano, El Colegio de México: Ciudad de México, Mexico, 1989. 
9. Azuela, A. (Ed.) Expropiación y Conflicto Social en Cinco Metrópolis de América Latina; Universidad Nacional Autónoma de México-Instituto de Investigaciones Sociales, Lincoln Institute of Land Policy: Cambridge, MA, USA, 2015.

10. Cruz, M.S. Las dimensiones rural y urbana en los espacios periféricos metropolitanos. El caso de la Zona Metropolitana del Valle de México. In Lo Urbano-Rural: ¿Nuevas Expresiones Territoriales? Ávila, H. (Coord.) UNAM: Ciudad de México, Mexico, 2005; pp. 179-205.

11. Cruz, M.S. Procesos urbanos y "ruralidad" en la periferia de la Zona Metropolitana de la Ciudad de México. Estud. Demográficos Urbanos 2002, 49, 39-76. [CrossRef]

12. Cruz, M.S. Propiedad de la tierra, urbanización ejidal y poblamiento en la Zona Metropolitana del Valle de México 1990-2000. Rev. Procur. Agrar. 2006, 38, 45-71.

13. Cruz, M.S. Urbanización y procesos locales en los pueblos del poniente de la zona metropolitana de la Ciudad de México. Carta Econ. Reg. 2019, 124, 57-81.

14. Frumkin, H.; Frank, L. Urban Sprawl and Public Health; Island Press: Washington, DC, USA, 2009.

15. Araghi, F.A. Global Depeasantization, 1945-1990. Sociol. Q. 1995, 36, 337-368. [CrossRef]

16. UN Habitat. New Urban Agenda adopted at Habitat III; UN Habitat: Quito, Ecuador, 2016.

17. United Nations. Growth of the World Urban and Rural Population, 1920-2000; United Nations: New York, NY, USA, 1969.

18. United Nations. World Urbanization Prospects: The 2003 Revision; United Nations: New York, NY, USA, 2004.

19. Araghi, F.A. The Invisible Hand and the Visible Foot: Peasants, Dispossession and Globalization. In Peasants and Globalization: Political Economy, Rural Transformation and the Agrarian Question; Akram-Lodhi, A., Kay, C., Eds.; Routledge: London, UK, 2008; pp. 111-147.

20. Loker, W.M. "Campesinos" and the crisis of modernization in Latin America. J. Pol. Ecol. 1996, 3, 69-88. [CrossRef]

21. Delgado, G.C. Ciudad y Buen Vivir: Ecología política urbana y alternativas para el bien común. THEOMAI 2015, 32, 36-56.

22. Brenner, N.; Schmid, C. The "Urban age" in Question. Int. J. Urb. Reg. Res. 2014, 38, 731-755. [CrossRef]

23. Lipton, M. Why Poor Peaople Stay Poor. A Study of Urban Bias in World Development; ANU Press: Canberra, Australia, 1977.

24. Martínez-Alier, J. The Environmentalism of the Poor. A Study of Ecological Conflicts and Valuation; Edward Elgar: Cheltenham, UK; Northampton, MA, USA, 2002.

25. Sánchez, C.; Díaz-Polanco, H. Pueblos, comunidades y ejidos en la dinámica ambiental de la Ciudad de México. Cuicuilco 2011, 52, 191-224.

26. OCDE. Estudios Territoriales de la OCDE: Valle de México, México. Sintesis del Estudio; OCDE: Ciudad de México, Mexico, 2015.

27. Olivera, G. La Urbanización Social y Privada del Ejido. Ensayos Sobre la Dualidad del Desarrollo Urbano en México; UNAM-CRIM: Cuernavaca, Mexico, 2015.

28. Sánchez, V.H. Ejidos urbanizados de Cuernavaca. Cult. Represent. Soc. 2006, 1, 67-92.

29. Paz, M.F.; Risdell, N. Conflictos, Conflictividades y Movilizaciones Socioambientales en México; Porrúa: Ciudad de México, Mexico, 2014.

30. Temper, L.; Del Bene, D.; Martínez-Alier, J. Mapping the frontiers and front lines of global environmental justice: The EJAtlas. J. Pol. Ecol. 2015, 22, 255-278. [CrossRef]

31. A Dictionary of Sociology: "Conurbation". Available online: http://www.encyclopedia.com/social-sciences/ dictionaries-thesauruses-pictures-and-press-releases/conurbation (accessed on 1 July 2017).

32. Aristegui Noticias: 7 Datos Sobre el Nuevo Aeropuerto de la Ciudad de México. Available online: http: //aristeguinoticias.com/0309/mexico/7-datos-sobre-el-nuevo-aeropuerto-de-la-ciudad-de-mexico/ (accessed on 12 July 2017).

33. Consejo de Pueblos de Morelos: Manifiesto de los Pueblos de Morelos. Available online: http://www. ecoportal.net/content/view/full/71751/ (accessed on 2 May 2017).

34. La Jornada: Carretera que Lesiona. Los de Abajo. Available online: http://www.jornada.unam.mx/2011/07/ 30/opinion/017o1pol (accessed on 3 July 2017).

35. La Jornada: Comunidades de Puebla se Oponen a Libramiento. Available online: http://www.jornada.unam. $\mathrm{mx} / 2010 / 11 / 22 /$ estados/035n1est (accessed on 4 July 2017). 
36. El Universal: Chocan Habitantes de Morelos y Policías por Abasto de Agua. Available online: http: //archivo.eluniversal.com.mx/primera/29012.html (accessed on 5 July 2017).

37. El Universal: Carretera Arco-Sur Afectará Siembra de Maíz y Nopal en Milpa Alta. Available online: http://www.eluniversaldf.mx/otrasdelegaciones/nota32206.html (accessed on 6 July 2017).

38. Cervantes, B.E. Percepción Pública Sobre Los Riesgos Ambientales y Riesgos a la Salud en Tepetzingo, Morelos, en el Contexto de la Construcción de la Unidad Habitacional La Ciénega. Estudio de Caso. Master's Thesis, Public Health, Specialization in Environmental Health, Escuela de Salud Pública de México, Instituto Nacional de Salud Pública, Cuernavaca, Mexico, 2010.

39. Arnaut, A. Movimientos sociales e identidad: El caso de los movimientos en Xoxocotla, Morelos. Cult. Represent. Soc. 2009, 4, 158-185.

40. GDF sin Indemnizar a Ejidatarios de Tláhuac por Construcción de Línea 12: PAN. Available online: http: //www.24-horas.mx/gdf-sin-indemnizar-a-ejidatarios-de-tlahuac-por-construccion-de-linea-12-pan/ (accessed on 7 July 2017).

41. Robles, H. Atenco: Un caso de terrorismo de Estado. Pap. Relac. Ecosociales Cambio Glob. 2010, 112, 131-140.

42. Desinformemonos: La Marina Insiste en Levantar un Cuartel Sobre las Tierras que Quitan la sed a la Ciudad de México. Available online: https://desinformemonos.org/la-marina-insiste-en-levantar-un-cuartel-sobrelas-tierras-que-quitan-la-sed-a-la-ciudad-de-mexico/ (accessed on 8 July 2017).

43. Proceso: La corrupción de OHL y los vínculos con Peña Nieto y Eruviel Ávila. Available online: http://www. proceso.com.mx/485640/la-corrupcion-ohl-los-vinculos-pena-nieto-eruviel-avila (accessed on 9 July 2017).

44. Merlinsky, M.G.; Latta, A. Environmental Collective Action, Justice and Institutional Change in Argentina. In Environment and Citizenship in Latin America: Natures, Subjects and Struggles; CEDLA Latin American Studies, Ed.; Berghahn Books: New York, NY, USA, 2012; pp. 190-208.

(C) 2019 by the authors. Licensee MDPI, Basel, Switzerland. This article is an open access article distributed under the terms and conditions of the Creative Commons Attribution (CC BY) license (http://creativecommons.org/licenses/by/4.0/). 